\title{
Hepatorenal Syndrome Associated with the use of Reishi Fungus
}

\author{
Tarık Ocak1, Arif Duran², Yavuz Katırcl³, Mansur Kürşad Erkuran², Bekir Barış Kurt²
}

'Department of Emergency Medicine, Kanuni Training and Research Hospital, İstanbul, Turkey

2Department of Emergency Medicine, Abant Izzet Baysal University School of Medicine, Bolu, Turkey

${ }^{3}$ Department of Emergency Medicine, Ankara Training and Research Hospital, Ankara, Turkey

\begin{abstract}
Introduction: Ganoderma lucidum, also known as red reishi mushroom, lingzhi, mannentake, and immortality mushroom, is the oldest known mushroom species used in Chinese and Japanese medicine for more than 2000 years.

Case Report: In our presentation, we aim to discuss the case of a 64-year-old male with acute hepatorenal failure associated with the use of reishi mushroom. He was brought to our hospital with complaints of palpitation and anuria since two days and altered mental status since one day.

Conclusion: Reishi mushroom may lead to hepatorenal failure. Just because of reasons mentioned above, legal sanctions and public education programs shall be organized to prevent this patient group from using herbal treatment as a result of overemphasized advertisements.
\end{abstract}

Keywords: Reishi fungus, acute hepatorenal failure, intensive care unit

Received: 20.11.2015 Accepted: 12.01.2016 Available Online Date: 16.02.2016

\section{Introduction}

Although the increase of popularity of alternative medicine and the development of unconscious use of herbal medicine has become a bridge of hope for some patients, some results have lead to troubles for patients as well as for physicians. Ganoderma lucidum, also known as lingzhi, mannentake, immortality mushroom, and red reishi mushroom, is the oldest known mushroom species used in Chinese and Japanese medicine, i.e. for more than 2000 years (1). It is believed that herbal drugs produced from this mushroom can cure diseases such as cardiovascular diseases, diabetes, renal failure, and cancers (1). In our presentation, we aim to discuss a case with acute hepatorenal failure associated with the use of reishi mushroom.

\section{Case Report}

Our patient, a 64-year-old male, was brought our hospital with complaints of palpitation and anuria since two days and altered mental status since one day. It was determined that angioplasty was applied to 2 veins, and a medical treatment was started because of heart attack. However, it was mentioned that our patient preferred to use herbal drugs instead of medical drugs and that he did not use the prescribed cardiac drugs. We learnt that the patient used a 400-mg oral tablet of reishi mushroom twice a day for 1.5 months. In his examination, we observed that he replied the questions with nonsense answers, Glasgow coma scale was counted as 12 (E3M5V4). In addition, the following values were obtained: arterial tension 80/40 mmHg, pulse $140 / \mathrm{min}$, fever $36.8^{\circ} \mathrm{C}$, respiratory rate $24 / \mathrm{min}$, and $\mathrm{SpO}_{2} 90 \%$. In arterial blood gas analysis, the following results were obtained: $\mathrm{pH}$ 7.17, $\mathrm{pCO}_{2} 13 \mathrm{mmHg}, \mathrm{pO}_{2} 99 \mathrm{mmHg}, \mathrm{HCO}_{3} 4.7 \mathrm{mmol} / \mathrm{L}, \mathrm{BE}-23.8 \mathrm{mmol} / \mathrm{L}$, and sO $296 \%$. In the electrocardiography, no pathology was observed except from sinus tachycardia. The laboratory results on a daily basis are presented in Table 1. Hepatitis markers (anti-Hbs $0.585 \mathrm{IU} / \mathrm{ml}$ negative and antiHCV $0.38 \mathrm{lU} / \mathrm{ml}$ negative) and the antiHIV $(0.267 \mathrm{IU} / \mathrm{ml}$ negative) were negative, which were examined to exclude viral hepatitis. When comparing clinical and laboratory data with those of previous days, a hepatorenal insufficiency with fulminant evolution was detected. No pathology was observed in brain tomography and abdomen ultrasonography. Dopamine infusion of $20 \mathrm{mg} / \mathrm{h}$ and combined hepatic amino acid solution and 10\% dextrose

Address for Correspondence:

Arif Duran, Department of Emergency Medicine, Abant Izzet Baysal University School of Medicine, Bolu, Turkey

E-mail:drarifduran@gmail.com

(c) Copyright 2016 by Emergency Physicians Association of Turkey - Available online at www.jemcr.org 
Table 1. Laboratory values according to the days

\begin{tabular}{|c|c|c|c|c|c|c|c|c|}
\hline Group & Analysis & 1 day before & $1^{\text {st }}$ day & $2^{\text {nd }}$ day & $3^{\text {rd }}$ day & $4^{\text {th }}$ day & $5^{\text {th }}$ day & $6^{\text {th }}$ day \\
\hline \multirow[t]{13}{*}{ Biochemistry } & $\operatorname{ALT}(\mathrm{U} / \mathrm{L})$ & 35 & $>4113$ & $>4113$ & 3835 & 2729 & 1935 & 1383 \\
\hline & Albumin (g/dL) & 3.2 & 3.0 & 3.1 & 3.4 & 3.0 & 2.8 & 3.5 \\
\hline & AST (U/L) & 128 & $>4202$ & $>4202$ & 2294 & 1010 & 403 & 197 \\
\hline & CRP (mg/L) & 15 & 23.80 & 65.37 & 79.61 & 65.21 & 46.00 & 34.48 \\
\hline & Glucose (mg/dL) & 104 & 271 & 99 & 104 & 91 & 103 & 110 \\
\hline & BUN (mg/dL) & 41 & 150 & 152 & 118 & 86 & 73 & 65 \\
\hline & $\mathrm{Cl}(\mathrm{mmol} / \mathrm{L})$ & 96 & 98 & 98 & 92 & 96 & 97 & 98 \\
\hline & CK (U/L) & 636 & 224 & 231 & & 73 & 49 & 45 \\
\hline & $\mathrm{Cr}(\mathrm{mg} / \mathrm{dL})$ & 0.76 & 2.98 & 2.54 & 1.64 & 1.07 & 0.84 & 0.75 \\
\hline & $\mathrm{LDH}(\mathrm{U} / \mathrm{L})$ & 510 & $>4500$ & 3337 & 816 & 597 & 430 & 350 \\
\hline & $\mathrm{Na}(\mathrm{mmol} / \mathrm{L})$ & 135 & 135 & 137 & 143 & 142 & 136 & 133 \\
\hline & $\mathrm{K}(\mathrm{mmol} / \mathrm{L})$ & 3.9 & 3.3 & 3.2 & 2.2 & 3.4 & 3.6 & 3.5 \\
\hline & Total Protein $(\mathrm{g} / \mathrm{dL})$ & 6.1 & 5.8 & 5.7 & 6.4 & 5.9 & 5.8 & 5.6 \\
\hline \multirow[t]{3}{*}{ Hematology Laboratory } & WBC $\left(K / \mathrm{mm}^{3}\right)$ & 11.4 & 21.22 & 12.20 & 12.29 & 11.44 & 9.96 & 11.11 \\
\hline & $\mathrm{Hgb}(\mathrm{g} / \mathrm{dL})$ & 13.6 & 13.2 & 13.7 & 15.1 & 14.9 & 14.3 & 14.1 \\
\hline & Platelet (K/uL) & 211 & 185 & 139 & 144 & 145 & 157 & 171 \\
\hline \multirow[t]{3}{*}{ Coagulation test } & APTT (second) & 46.2 & 159.8 & 33.9 & 27.2 & 27.8 & 30.4 & 32.9 \\
\hline & INR & 1.5 & 2.62 & 2.10 & 1.53 & 1.43 & 1.37 & 1.32 \\
\hline & PT (second) & 38 & 35 & 44 & 61 & 65 & 69 & 71 \\
\hline
\end{tabular}

infusion of $80 \mathrm{cc} / \mathrm{h}$ was applied. In addition, $\mathrm{NaHCO}_{3}$ infusion of 2 amp/h (10 mL of 8.4\%) was started intravenously. $\mathrm{N}$-acetyl cysteine infusions of $150 \mathrm{mg} / \mathrm{h}$ for $1 \mathrm{~h}, 50 \mathrm{mg} / \mathrm{h}$ for $4 \mathrm{~h}$, and $100 \mathrm{mg} / \mathrm{h}$ for 16 $\mathrm{h}$ were intravenously applied for the patient who was hospitalized in intensive care unit. In addition to all these treatments, intravenous K-vitamin ampule of $20 \mathrm{mg} /$ day, fresh frozen plasma of 2 units/day, and crystallized penicillin of $4 \times 6 \mathrm{mU}$ were started. Hemodialysis was performed for two hours, then $0.9 \% \mathrm{NaCl}$ infusion at $100 \mathrm{cc} / 24$ $\mathrm{h}$ with a central venous pressure monitoring was administered. At the sixth hour of the follow-up, a regular urine output had started at $150 \mathrm{cc} / \mathrm{h}$, the patient was conscious, the vital signs were stable, and the Glasgow coma scale score was 15 (E4M6V5). The patient was discharged on the seventh day of his treatment with the improvement in his clinical and laboratory data.

\section{Discussion}

Traditional Asian herbal remedies are becoming increasingly popular in many countries. G. lucidum, a dry preparation of fungus, is a generally used Chinese medicine. It has hepatoprotective, cytoprotective, antioxidant, and antitumor effects (2). It has been generally used as self-medication for the treatment and prevention of various medical diseases. It is traditional to coddle G. lucidum for use for digestion without any additional preparation. Prepared products of G. lucidum either in the form of dust or tablets are now present for general consumption (3). Our patient used a 400-mg tablet without prescription. These dissimilar formulations of products generally required addition of other materials, which can be potentially toxic to the liver. Herbal hepatotoxicity or herb-induced liver injury (HILI) is rare and represents a bundle of disorders, each characterized by a specific herb or herbal mixture considered as potentially hepatotoxic (4). Drug-induced liver injury and HILI are complex diseases and often overdiagnosed (5). Our patient's The Council for International Organizations of Medical Sciences/Roussel Uclaf Causality Assessment Method scale was 13. Total score with resulting causality grading $\geq 9$, so it is highly probable to have cholestatic or mixed type of liver injury (7). Hepatotoxicity caused by herbal traditional Chinese medicine (TCM) is reported from many countries around the world: China, Taiwan, Hong Kong, Japan, Singapore, Korea, Thailand, Italy, Australia, France, Spain, the Netherlands, the United Kingdom, Iceland, Canada, the United States, and Argentina (6). In the past 3 years, new cases of such neglected liver disease with substantially improved data presentation were published and renewed the scientific interest (7). Since 2011, new case reports and case series of herbal hepatotoxicity due to the consumption of TCM have emerged (8). Healthcare staff should inform possible consumers of herbal TCM about the risks and benefits (9). Hepatotoxicity risk of herbal TCM and the ratio of damage/benefit are clearly negative (3). The development activity of pharmacovigilance is hopeful for the prevention 
of all these troubles. Herbal treatment has been used in Turkey since 2009; the number of people using it is increasing. We believe that the most important factor for this are the advertisement works. The tablet forms of G. lucidum (400 mg), which does not grow in Turkey, are sold upon authorization by the Ministry of Agriculture And Livestock. We rarely meet people who prefer to use herbal drugs instead of medical drugs like our patient in the population. These individuals consider herbal drugs as miracle drugs that will treat them. The induction of cytochrome P450 enzymes by other therapeutic agent(s) in the previous and available cases may synergistically augment the production of toxic metabolite derived from lingzhi dust (10). It is not easy to exclude the possibility of idiosyncratic or adverse reaction for some individuals. The primary symptoms of hepatitis may not be identified because of the difficulty in verbal communication with the psychotic patient. The prolonged intake of the agent may due to repetitive injuries to liver cells followed by extensive zonal necrosis (13). However, there are no studies about regarding the blood levels of the drug, the dose, the time, the effect, and how they are released from the body for these preparations, and they only rely on advices. In the cases presented by Wanmuang et al. (10), it has been determined that ceftriaxone has been used instead of crystallized penicillin, and no hemodialysis has been planified in spite of the expected liver transplantation. We had to plan the treatment of our patient as a general mushroom treatment because there were not enough case studies in the literature or no standard treatment protocol.

\section{Conclusion}

Considering the prognosis and the survival, we can say that we obtained a positive result; however, further studies are required about this issue. The group of patients using herbal drugs instead of medical treatment constitutes an important health issue besides the unconscious drug use. Legal sanctions and public education shall be organized to prevent this patient group from using herbal treatment as a result of overemphasized advertisements.

Informed Consent: Written informed consent was obtained from patient who participated in this case.
Peer-review: Externally peer-reviewed.

Author Contributions: Concept - T.O.; Design - A.D.; Supervision - Y.K.; Materials - M.K.E., B.B.K.; Data Collection and/or Processing - M.K.E., B.B.K.; Analysis and/or Interpretation - A.D., T.O.; Literature Review - A.D., Y.K.; Writer - A.D., Y.K.; Critical Review - T.O.

Conflict of Interest: The authors declared no conflict of interest.

Financial Disclosure: The authors declared that this study has received no financial support.

\section{References}

1. Chen SN, Chang CS, Hung MH, Chen S, Wang W, Tai CJ, et al. The Effect of Mushroom Beta-Glucans from Solid Culture of Ganoderma lucidum on Inhibition of the Primary Tumor Metastasis. Evid Based Complement Alternat Med 2014; 2014: 252171

2. Gao Y, Zhou S, Jiang W, Huang M, Dai X. Effects of ganopoly (a Ganoderma lucidum polysaccharide extract) on the immune functions in advancedstage cancer patients. Immunol Invest 2003; 32: 201-15. [CrossRef]

3. Teschke R, Wolff A, Frenzel C, Schulze J. Review article: Herbal hepatotoxicity - an update on traditional Chinese medicine preparations. Aliment Pharmacol Ther 2014; 40: 32-50. [CrossRef]

4. Bunchorntavakul C, Reddy KR. Review article: herbal and dietary supplement hepatotoxicity. Aliment Pharmacol Ther 2013; 37: 3-17. [CrossRef]

5. Teschke R, Wolff A, Frenzel C, Schwarzenboeck A, Schulze J, Eickhoff A. Drug and herb induced liver injury: Council for International Organizations of Medical Sciences scale for causality assessment World J Hepatol 2014; 6: 17-32.

6. National Institutes of Health $(\mathrm{NIH})$ and LiverTox. Chinese and other Asian herbal medicines. Last updated January 10, 2014. Available at http://livertox.nih.gov/ChineseAndOtherAsianHerbalMedicines.htm. Accessed March 15, 2014.

7. Rossi S, Navarro VJ. Herbs and liver injury: a clinical perspective. Clin Gastroenterol Hepatol. 2014; 12: 1069-76. [CrossRef]

8. Stedman C. Herbal hepatotoxicity. Semin Liver Dis 2002; 22: 195-206. [CrossRef]

9. Teschke R. Traditional Chinese Medicine induced liver injury. J Clin Translat Hepatol 2014; 2: 80-94. [CrossRef]

10. Wanmuang H, Leopairut J, Kositchaiwat C, Wananukul W, Bunyaratvej S Fatal Fulminant Hepatitis Associated with Ganoderma lucidum (Lingzhi) Mushroom Powder J Med Assoc Thai 2007; 90: 179-81. 